\title{
China's UN Peacekeeping in Mali and Comprehensive Diplomacy
}

\author{
Marc Lanteigne 1
}

\section{Abstract}

China's increasing participation in United Nations peacekeeping operations reached a milestone in 2013 when Beijing agreed to send a large detachment of personnel, including combat forces for the first time, to support UN peacekeeping operations in Mali after that country fell into civil war. This commitment was also distinct in that unlike other African countries where Beijing has supplied peacekeepers, Mali is not a major trading partner with China. However, this mission has both cemented Beijing's greater commitment to building African partnerships as well as demonstrating its determination to move beyond 'resource diplomacy' and towards a more comprehensive approach to engaging the continent. Although China has warmed to the principles of humanitarian intervention in civil conflicts, Mali has been a critical test of China's ability to participate in UN operations in a country which is still facing ongoing violence. The Mali mission is an important step in Beijing's turn towards greater realpolitik in Chinese Beijing's peacekeeping policies in keeping with its great power status. At the same time, participation in the Mali mission been beneficial for China, not only in helping to build the country's peacekeeping credentials in Africa but also in underscoring China's increasingly distinct views on addressing intervention in civil conflicts.

Keywords: China, Mali, peacekeeping, Africa, United Nations, MINUSMA

\section{Introduction: The Mali Challenge}

In mid-2013, China's increasingly positive views towards United Nations peacekeeping faced a critical test when Beijing, under the newly installed government of Xi Jinping, agreed to send a large detachment of personnel, including, for the first time, combat forces, to assist with bringing peace to the West African state of Mali. This operation was the Mission multidimensionnelle intégrée des Nations Unies pour la stabilisation au Mali (United Nations Multidimensional Integrated Stabilization Mission in Mali, or MINUSMA), with a mandate to assist with the pacification of the country after it fell into civil war in early 2012. China's commitment was notable in that Beijing's offer of personnel was not perceived as having an economic rationale, unlike other Chinese African peacekeeping commitments such as in Sudan and South Sudan which were heavily influenced by resource diplomacy. ${ }^{2}$ Rather, Beijing's decision to contribute personnel and logistic support confirmed China's greater commitment to building African partnerships under the Xi government, while promoting an alternative approach to peacekeeping and peace-building, to counter a perceived 'neo-

\footnotetext{
The author wishes to thank Lynn Gardinier, Courtney Fung and Mingming Shi for their assistance with the researching and preparations for this article, as well as the Institute of International Relations and Area Studies at Ritsumeikan University, Kyoto, for their financial support for the original presentation of this research.

${ }^{1}$ Political Science, UiT-The Arctic University of Norway, marc.lanteigne@uit.no.

${ }^{2}$ Verhoeven, 2014; Hanauer and Morris, 2014.
} 
colonialist' policy towards Mali by the West, most notably France, the colonial overseer of Mali before the African state's independence in 1960. However, the Mali mission also offered China the opportunity to enhance its reputation in Africa as a partner with interests beyond the strictly economic.

Despite the lack of a strong trading relationship between China and Mali, with the latter country is not as resource rich as other parts of the continent, Beijing is seeking to strengthen its overall economic relations with Africa via both bilateral links and more ambitious plans including the Belt and Road Initiative (yidai yilu一带一路) or BRI, created under $\mathrm{Xi}$ in 2013, as well as more region-specific diplomacy such as the Forum on ChinaAfrica Cooperation (FOCAC). Evidence of that commitment includes China's contribution to Mali peacekeeping, despite the considerable risk to Chinese personnel. Other peacekeeping missions in which China is participating, including those in Africa, have involved complex on-the-ground security challenges, with South Sudan as the most glaring example. ${ }^{3}$ Yet the current strategic situation in Mali is a particularly virulent mix of weak state structures and both internal and external sources of terrorism and destabilisation, including local extremist elements and adherents of the global terrorist organisations Al-Qaeda and the Islamic State (IS).

Although China has warmed to the principles of humanitarian intervention in civil conflicts over the past two decades, it retains a degree of wariness towards peacebuilding operations outside the sponsorship of the UN. The Mali mission has been beneficial for China, not only in building its peacekeeping credentials in Africa but also in underscoring China's increasingly distinct, 'neo-Westphalian' views on addressing intervention in domestic conflicts. Moreover, China's policies in Mali are an essential part of a multifaceted, 'comprehensive' diplomatic push in Africa seeking to build a Chinese identity both as an economic partner and an ally in addressing multifaceted security challenges on the continent.

The situation in Mali remains unstable and on a daily basis, continues to place UN forces in harm's way. ${ }^{4}$ Since 2014, France, the main external actor in the conflict has begun to fold its policies regarding the Mali conflict into the greater instability concerns facing much of the Sahel region in north-west Africa, including in nearby Niger, a tactic which Beijing is also beginning to adapt. Chinese forces, and civilians, have faced dangers in Mali, with casualties and no definite timetable for the success of the UN mission. In addition to the greater international community, MINUSMA is also providing difficult lessons for China about the unpredictable nature of modern UN peacekeeping and the responsibilities of great power status, especially as the country becomes increasingly engaged in conflicts beyond the Asia-Pacific and within intra-state conflicts. China is therefore seeking to continue to deepen and diversify its commitments to UN peace operations while increasing its understanding of the promise and perils of modern peacekeeping as well as the greater questions of intervention in humanitarian emergencies.

\section{China's Changed Views on UN Peacekeeping}

Since the People's Republic of China joined the United Nations in 1971, there has been a significant evolution in Beijing's overall view of UN peacekeeping, from opposition and wariness to a supportive stance and active participation, including in Africa. During the past decade, Beijing has been more willing to make personnel commitments beyond strictly support roles such as civilian police and specialist engineers to now include combat forces.,

\footnotetext{
${ }^{3}$ Huang, 2018.

${ }^{4}$ Human Rights Watch, 21 December 2017; Chandler and Zogg, 2017.
} 
Beijing began its first major forays into UN peace operations in the 1990s, when there was a marked preference for sending only observers, one early exception being the UN Transitional Authority in Cambodia (UNTAC) in 1992-3 when two Chinese engineering battalions were deployed. $^{5}$

Between 1999-2002, Beijing also agreed to send civilian police units as liaisons with a standing UN mission, namely the United Nations Transitional Administration in East Timor (UNTAET), despite that conflict involving a crisis involving separatism, normally an anathema to Chinese foreign policy given the Taiwan factor. ${ }^{6}$ Since the 1990 s, China has sent both military personnel and civilian policy officials to several disparate UN missions in the Middle East, Africa, Southeast Asia and the Caribbean, and by 2009 China had overtaken France as the largest supplier of UN peacekeeping personnel within the 'permanent five' members of the United Nations Security Council (UNSC). As of December 2017, China had approximately $2600 \mathrm{UN}$ personnel stationed abroad, out of approximately $96,600 \mathrm{in}^{\mathrm{n}}$ total. $^{7}$ Beijing also substantially increased its share of the UN peacekeeping budget over the past decade, from $3.9 \%$ in 2012 to $6.6 \%$ in 2015 , as compared with the United States (28\%), Japan $(10.8 \%)$ and France (7.2\%). Then, in May 2016, Beijing announced that it would once more augment its share of the UN peacekeeping budget, contributing 10.3 percent between 2016 and 2018, thus making China the second-largest contributor after the US. ${ }^{8}$

During an address to the UN General Assembly in September 2015, President Xi also announced the creation of a standby UN force of eight thousand Chinese personnel, along with a ten-year US\$1 billion fund for joint Chinese-United Nations peace initiatives during the following decade, and US\$100 million to be donated to African security initiatives over a period of five years. According to the Chinese Defence Ministry, the 8000 personnel were all registered as of September 2017, with eight hundred and fifty of these slated to become a part of a UN rapid-response force, known as the 'Vanguard Brigade'.?

Beijing's growing and diversified contributions to UN peacekeeping operations, as well as its greater commitment to addressing humanitarian emergencies abroad, have become a source of pride for the country's security establishment while blunting international concerns about the rise of Chinese military power. ${ }^{10}$ This is also an oft-cited example of its commitment to evolving as a great power via the doctrine of 'peaceful development' (heping fazhan 和平发展), introduced at the start of the Hu Jintao presidency in 2003. China's UN commitments were more fully developed under the Xi government in order to illustrate the country's expanded foreign policy interests, including being more cooperative and supportive of multilateral operations designed to improve security abroad, but also in ways contrasting

\footnotetext{
${ }^{5}$ Hirono, 2011; Chen, 2009.

${ }^{6}$ Lanteigne, 2011.

7 'Monthly Summary of Contributions (Police, UN Military Experts on Mission and Troops), as of 31 December 2017, United Nations, January 2018,

$<$ https://peacekeeping.un.org/sites/default/files/summary_of_contributions_to_peackeeping_by_mission_country _and_post.pdf $>$.

8 'Implementation of General Assembly Resolutions 55/235 and 55/236

Report of the Secretary-General, United Nations General Assembly A/67/224/Add.1, 27 December 2012,

$<$ http://www.un.org/en/ga/search/view_doc.asp?symbol=A/67/224/Add.1>; China Daily, 30 May 2016.

${ }^{9} \mathrm{Xi}, 2017$, 569-75; Zheng, 2017; Bo, 2017.

${ }^{10}$ Fung, 2016.
} 
with those of the West. At the same time, China's security interests have expanded in proportion to the numbers of Chinese citizens and assets abroad. These Chinese policies were in keeping with being a 'responsible great power' (fuzeren de daguo 负责人的大国), while moving away from the 'lying low' (taoguang yanghui 蹈光养晦) strategy prevalent in Chinese foreign policy since the 1980s, and gaining further global recognition for the country's alternative models of strategic cooperation, ${ }^{11}$ particularly in developing regions.

Despite the more favourable stance towards multilateralism, Chinese policy remains influenced by the cold war-era 'Five Principles of Peaceful Coexistence' (hepinggong chuwuxiang yuanze 和平共处五项原则), the early Maoist-era doctrine which advocated respect for sovereignty and non-interference in states' sovereign affairs. ${ }^{12}$ The ideas prompting a revision of China's thinking on peacekeeping began to coalesce in the middle of that decade and continued into the current century under Hu Jintao. They became more complex as Beijing began to expand its diplomacy beyond Asia and into cross-regional policies which, by necessity, prompted a greater Chinese role not only in economic partnerships but also in security problems further from the country's periphery, including in Africa, an area in which much of the recent Chinese cross-regional diplomacy has been evident. $^{13}$

Beijing's changed views on multilateralism and security developed during a period in the 1990s when Chinese policy began to acknowledge the reality that many security problems could not be effectively addressed unilaterally, with cooperation often a more effective method of developing both security and confidence-building. By the end of the decade, after demonstrating wariness towards the ideas of 'human security' (ren de anquan 人的安全) namely the blending of human rights issues with security initiatives and placing a greater focus on the individual rather than on the state, Beijing began to examine this branch of security much more closely, although Chinese policy circles favoured the use of the lesspolitically sensitive term 'non-traditional security' (fei chuantong anquan 非传统安全). There was a growing concern that retaining cold war-era perceptions of security would be detrimental in facing a growing number and variety of non-state security challenges, including global terrorism and the destabilising effects of state collapse, especially in regions where China was developing stronger economic interests. ${ }^{14}$ Non-traditional security challenges have now become embedded in modern Chinese military strategy, including in crucial economic regions such as Africa, and have played a part since the mid-2000s in China's pursuit of engaging in 'long-distance manoeuvres' (changtu yanxi 长途演习), ${ }^{15}$ including overseas peacekeeping.

However, as China's peacekeeping policy matured and as international security issues began to increase in complexity and interconnectedness, there was a growing realisation in Beijing that it would have to reconsider its peacekeeping policies to prepare itself for 'multifunctional' (duogongneng 多功能) missions, prompting much internal debate within China not only over policy but also whether new and broader thinking on Beijing's part was

\footnotetext{
${ }^{11}$ Richardson, 2011; Poh and Li, 2017.

${ }^{12}$ MFA China, 2000.

${ }^{13}$ Brautigam, 2009; Gadzala, 2015.

${ }^{14}$ Evans, 2004, 275.

${ }^{15}$ Holsag, 2009, 109.
} 
required. ${ }^{16}$ Much of China's initial peacekeeping policies, it had been argued, were dominated by 'first generation peacekeeping' (yidai weihe 一代维和) practices, echoing cold-war era UN operations with a stronger emphasis on maintaining sovereignty, neutrality and the pursuit of consent, as opposed to the more multifaceted, 'robust peacekeeping' (qiangzhuang weihe 强 壮维和), more commonplace after the 1990s as civil conflicts became more prevalent. China's growing global diplomatic, strategic and economic interests, as well as the country's increasing acceptance of the principles of 'responsibility to protect' (baohu de zeren 保护的责 任) or R2P, all prompted a revisiting of the 'robust' peacekeeping question, ${ }^{17}$ including whether China would be in a position to provide combat forces in addition to support and engineering personnel. It is argued that although China has developed a greater understanding and appreciation of R2P, much difference of opinion remains within the country as to how best to pursue them while still retaining support for Westphalian sovereignty. ${ }^{18}$

The widening and deepening of Beijing's UNPKO interests since the late 1990s also served to augment Chinese 'soft power' in key regions such as Africa, while mitigating the perception of a looming 'China threat' (Zhongguo weixie 中国威胁) especially in the developing world. ${ }^{19}$ Since Xi Jinping assumed office, all signs have indicated that Beijing continues to seek methods of deepening its developing country partnerships, many of which have been based on increased trade, especially in raw materials considered essential to the continuing growth of the Chinese economy. In many aspects of Chinese diplomacy in the developing world, there remain many vestiges of 1990s-era 'large developing country' (fanzhanzhong daguo 发展中大国) thinking which, in the case of its UN peacekeeping policies, have served the country's interests well. ${ }^{20}$ However, with China's increasing power, an argument can be made that the country's 'middle power' approach to peacekeeping may be eroding, especially in light of the commencement of Belt and Road investments and projects which have included Africa in a more overt fashion. ${ }^{21}$ Therefore, China may be viewing its current peacekeeping policy as a window of opportunity which will not be open indefinitely.

China currently remains openly supportive of the principles of UN peacekeeping, both as a way of prompting peaceful multilateral settlement of disputes and more frequently to include Chinese armed forces in 'military operations other than war', or Mоотw (feizhanzheng xing junshi xingdong 非战争性军事行动). These include humanitarian missions, disaster relief, and increasingly, peacekeeping missions. The MоOTw concept, which has been included in Chinese Defence White Papers since 2008, offered an opportunity for the country to demonstrate the expansion of its military capabilities in a cooperative manner. Peacekeeping has been viewed by the Chinese military as a main component of MoOTw missions, along with counter-terrorism, relief and rescue. ${ }^{22}$ However, the case of Mali has demonstrated to Beijing that deepening Chinese support for modern UN peacekeeping operations is not without risks and complicated questions, including in the areas of

\footnotetext{
${ }^{16}$ Wang, 2012.

${ }^{17}$ Pang, 2009; Pang, 2012, 54-5; Teitt, 2011.

${ }^{18}$ Zheng, 2016.

${ }^{19}$ Yong, 2006.

${ }^{20}$ Hirono and Lanteigne, 2012.

${ }^{21}$ Ehizuelen and Abdi, 2017.

${ }^{22}$ Gill and Huang, 2009; Fravel, 2001; Clemens, 2016.
} 
peacekeeping under combat conditions, cooperation with other major external stakeholders, and defining the criteria for successful missions and achieved goals, not only for the United Nations but also for China's own security concerns as the country's economic interests continue to become globalised. Thus, difficult decisions about previously held views and ideologies by the Xi government were required in response to 'messy' peacekeeping operations such as the ongoing Mali mission.

\section{A Thousand Cuts: The Trials of Mali}

China's attempts to juggle both its suspicions of Western interventionist policies and its own expanding economic diplomacy in the developing world, notably Africa, were seriously challenged by events in the north-western part of the continent in 2012-3. The state of Mali first drew the attention of the United Nations due to a growing separatist movement in the desolate, underdeveloped north-eastern part of the country. Prior to independence, Mali was part of greater French West Africa, and it remains one of the poorest nations on the continent, with a per capita GDP of approximately US\$1100 and an economy based on agriculture, (primarily cotton), and gold mining. The landlocked country's sparse population, (14.5 million), is primarily based in the south, primarily within the capital of Bamako. The northern part of the country, which abuts the Sahara, is sparsely populated with comparatively more porous borders. The country's location, surrounded by conflicts and instability in Algeria, Chad, Côte d'Ivoire, Libya and Niger, as well as the aftershocks of the post-2010 'Arab Spring' uprisings across North Africa and Southwest Asia, left the country and the overall region, vulnerable to a 'bad neighbourhood' security dilemma, in terms of illegal immigration, weapons smuggling and radicalization. ${ }^{23}$

One of these recent conflicts, the civil war in Libya since 2011, which resulted in the ouster of leader Muammar Gaddafi and the splintering of the country between several factions, including the local branch of the Islamic State as well as local support groups, was widely seen as the main catalyst for greater instability in much of the Sahel region. ${ }^{24}$ Insurgents and extremists involved in that conflict began to base operations in the desolate regions of northern Mali, along with weapons appropriated from the Libyan fighting, in the hopes of creating a more permanent redoubt in the Sahel. By early 2012, local militants sought to create a separate state of Azawad, forcibly carved out of Mali's northern desert regions, drawing from Tuareg (Berber) nomads in the territory who had been largely disenfranchised, socially and economically, from the more prosperous south and the central government in Bamako.

What would otherwise have been a relatively limited insurgency soon developed into an international concern when the separatists joined with a second coalition of extremists, headed by the Ansar Dine (Ansar al-Din, or 'Defenders of the Faith') and backed by AlQaïda au Maghreb islamique / Al-Qaeda in the Islamic Maghreb (AQIM). The Ansar Dine had been a longstanding opponent of the Malian government and a supporter of Tuareg independence, as well as the implementation of strict shari'a law across Mali. The AQIM, primarily based in Algeria, acted as Al-Qaeda's main arm in North Africa since its organization was formalized in 2007, with a splinter group, al-Mulathamin ('the Masked Ones') operating in northern Mali. ${ }^{25}$ Two other Islamic fundamentalist groups, Le Mouvement

\footnotetext{
${ }^{23}$ Elischer, 2013; English, 2017.

${ }^{24}$ Rettman, 2012, Heisbourg, 2013.

${ }^{25}$ Shaw, 2013; Black, 2013; Bøås and Torheim, 2013.
} 
pour l'Unicité et le Jihad en Afrique de l'Ouest ('Movement for Oneness and Jihad in West Africa') and Boko Haram, operating out of northern Nigeria, further destabilized northern Mali and began to capture towns throughout the region while flush with smuggled arms and trained militants both from within Mali and from the nearby Libyan conflict. ${ }^{26}$

In April 2012, the rebels captured the ancient city of Timbuktu (Tombouctou), threatening ancient texts and other historical relics in the centuries-old settlement, and by January 2013 the strategically important town of Konna, seven hundred kilometres from Bamako, was also overrun, underscoring the vulnerability of the the capital to attack by rebel forces. ${ }^{27}$ The civilian government began to be viewed as incapable of properly addressing the conflict, and the country descended further into anarchy in March 2012 when a military coup ousted President Amadou Toumani Touré over the civilian government's inability to northern security crises, domestic differences in Malian constitutional reforms, and fears that the country could not battle the insurgents without outside assistance. ${ }^{28}$ However, rather than strengthen the resolve of the Malian Armée de Terre, the coup accomplished the opposite, including mutinies and additional disorder which allowed the various rebel groups to gain still more territory with negligible opposition.

The interim military government headed by Dioncounda Traoré thus requested French military assistance in early January 2013 as the security situation continued to worsen and it became apparent that despite concerns in North Africa over Mali's deepening crisis, regional security mechanisms lacked both the coordination and the resolve to respond. A cautiouslyworded report on the Mali situation released by the UN Secretary-General in November 2012, as well as two UNSC resolutions which essentially placed the onus of solving the crisis on the fractured Malian government, also raised concerns that the organisation was not prepared to respond effectively to calls for outside intervention. ${ }^{29}$

France, therefore, was facing mounting pressure to respond to the crisis, unilaterally if necessary. ${ }^{30}$ In the face of these developments, at the beginning of 2013 the then-government of François Hollande controversially reversed its decision made during previous October that France's support for the Malian government would be restricted solely to material goods. ${ }^{31}$ During an October 2012 parliamentary speech in Dakar, Senegal, Hollande sought to assure African leaders that France was moving away from its previous hegemonic role in the region. ${ }^{32}$ However, with the announcement that France would go it alone, or at least with African allies and without other Western ones in rolling back extremist forces in Mali, it was demonstrated that France was not going to be abandoning its security interests in the Sahel

\footnotetext{
${ }^{26}$ Shaw, 2013; Zajec, 2013.

${ }^{27}$ France 24 / AP, 2013; Hammer, 2014.

${ }^{28}$ Lacocq, et al. 2013, Wing, 2015.

${ }^{29}$ Lecocq et al., 2013. 'Report of the Secretary-General on the Situation in Mali,' United Nations Security Council Secretary-General's Report S/2012/894, 28 November 2012,

$<$ http://www.un.org/en/ga/search/view_doc.asp?symbol=S/2012/894>.

${ }^{30}$ Cristiani and Fabiani, 2013.

${ }^{31}$ Wing, 2013.

${ }^{32}$ France Diplomatie, 2012.
} 
region. French military intervention under Opération Serval began in January 2013 with the blessing of several Western European governments and the United States. ${ }^{33}$

As Islamist forces continued to threaten the capital, the United Nations authorised the intervention of French and African troops to push the rebels back during the first half of 2013, recapturing all key towns in the north by the end of January. ${ }^{34}$ A provisional peace agreement between Bamako and the Tuareg rebels was signed in June 2013, with an election successfully held the following month. However, due to sporadic attacks by extremist rebel militias and irregulars, the country's northern regions remained unstable even after foreign forces arrived in Mali. Following the signing of the peace agreement, the UN authorized the formation of MINUSMA whose mandate included the re-establishment of Malian state authority throughout the country as well as the protection of civilians and ancient sites. The mission was authorised after the successful April 2013 passing of UN Security Council Resolution 2100(2013) which authorised approximately 11,200 personnel to be deployed in Mali under the United Nations. ${ }^{35}$ France, however, would remain at the forefront of peace operations, with the goal for Paris and the international community being not only ending the Malian conflict, but also stabilising the Greater Sahel region.

For Beijing, the events of early 2013 in Mali were especially unsettling for several reasons. First, the Chinese government was dismayed at the possibility of another civil conflict spilling over into a region where Beijing had a growing number of economic interests. Second, Beijing was also concerned that France would view Opération Serval as a 'Trojan Horse' policy to tacitly revive its dominant position the Sahel region, ${ }^{36}$ especially in the wake of Chinese frustration over what it saw as the West's mishandling of UN resolutions to protect civilians during the start of the Libyan civil war. In a significant departure from Beijing's traditional views on non-interference in individual states' sovereign affairs, China had opted to abstain in an UNSC vote in March 2011 which created a 'no-fly zone' over Libyan airspace and permitted the UN to protect civilians from attack. However, Beijing was dismayed with subsequent NATO airstrikes on Libya which accelerated the fall of the Gaddafi regime, actions which Beijing saw as flagrant abuse of a UNSC mandate and the possible setting of a precedent. ${ }^{37}$ These factors helped focussed Chinese attention on the greater regional ramifications of Mali's potentially violent disintegration, and prompted the subsequent decision by Beijing, which had initially supported the creation of MINUSMA, to participate more directly in the peacekeeping mission.

In December 2013, China sent 135 personnel, including engineers and medical staff as well as, for the first time, combat forces with a mandate beyond just the protection of Chinese personnel, to Mali as an advance team for an overall initial force of 395 persons within the UN operation. As of December 2017, five Chinese peacekeeping missions had been deployed to Mali, with slightly less than four hundred Chinese personnel on the ground at the end of that year, and in February 2018, members of the fifth Chinese MINUSMA force was chosen

\footnotetext{
${ }^{33}$ Boeke and Schuurman,, 2015.

${ }^{34}$ Polgreen and Sayare, 2013.

${ }^{35}$ United Nations Security Council Resolution 2100(2013), 25 April 2013, S/RES/2100 (2013),

$<$ http://www.un.org/en/peacekeeping/missions/minusma/documents/mali\%20_2100_E_.pdf $>$

${ }^{36}$ Avezov and Smit, 2014.

${ }^{37}$ Garwood-Gowers, 2012; Snetkov and Lanteigne, 2015.
} 
to receive the UN's Peace Medals of Honour in recognition of their service. In April of that year, a sixth detachment of 395 peacekeepers was confirmed for the following month. ${ }^{38}$

\section{China's Rationales for Entering the Mali Mission}

Since MINUSMA's creation, the Mali conflict has proven to be a crucial test of Chinese commitments to peace operations for several reasons. First, the decision to send combat forces to a UN mission was a watershed event, as previously Beijing preferred to restrict its contributions of UN personnel to civilian police, normally drawn from civilian units and the People's Armed Police (PAP), as well as engineers, medical and other support staff. The strategic component of the force would be drawn from the $16^{\text {th }}$ Combined Corps of the Shenyang Military Area Command of the People's Liberation Army (PLA). ${ }^{39}$ This had been a delicate subject in Chinese policymaking circles at least as far back as 2006 when Beijing contemplated adding combat forces to its contribution to UN peacekeeping operations in Lebanon, but ultimately decided against that option. Although the Chinese government did make mention of the added security component to its contribution to the Mali operation, this was done in a muted fashion, downplaying the military aspect of its participation. The fact that the UN peacekeeping operations in Mali were designed to protect a regime, rather than to undermine or depose one, was also a factor in China's decision to participate as well as to include a security force component. ${ }^{40}$

Second, unlike in other parts of Africa where Chinese peacekeeping personnel had been committed, notably Sudan and South Sudan, Mali was not a major economic partner for China, nor did Mali have a resource base which Chinese firms were actively seeking to codevelop. However, the Mali mission did play a part in China's wider diplomatic engagement of Africa which began under President Hu's cross-regional diplomacy in Africa, a process expanded under Xi Jinping. Mali had played a role in China's expanding African diplomacy after the turn of the century. For example, Malian leaders visited China four times in the period of 2004-10, and Hu Jintao toured Mali in February 2009 as part of his government's expanded cross-regional diplomatic policies in Africa. ${ }^{41}$ Agreeing to participate in the UN Mali operations permitted Beijing to assuage global concerns that China's African diplomacy was based solely on resource extraction. This stance would assume even greater importance after the Belt and Road policies began to be unveiled later in 2013. At the same time, Beijing was becoming sensitive to Western views, including from then-US President Barack

Obama, ${ }^{42}$ that China was 'free riding' on American and Western-led military operations, and Mali provided an opportunity for Beijing to more directly demonstrate its commitment to African security.

\footnotetext{
${ }^{38}$ Xinhua, 5 December 2013; 'Summary of Contributions to UN Peacekeeping by Country, Mission and Post / Police, UN Military Experts on Mission, Staff Officers and Troops, 31/12/2017,' United Nations, January 2018, $<$ https://peacekeeping.un.org/sites/default/files/summary_of_contributions_to_un_peacekeeping_by_country_mis sion_and_post.pdf>; Xinhua, 11 May 2017; Xinhua, 19 April 2018; China Ministry of Defence, 24 February 2018 .

${ }^{39}$ People's Daily, 20 November 2013,

${ }^{40}$ Murray, 2013. Hille, 2013; Foot, 2014, 1087.

${ }^{41}$ People's Daily, 14 February 2009.

${ }^{42}$ Feng, 2014.
} 
Third, China's swift commitment of UN personnel in early 2013 to the Mali operation demonstrated not only a firm commitment to peacekeeping but also an acknowledgement of the growing connections between poverty and insecurity, including in unstable regions in Africa like the Sahel. In 2013, China used the Mali intervention to return to its earlier diplomatic stances, equating state instability with economic underdevelopment. As one editorial in the China Daily noted, while France's actions worked to prevent the brand of radical extremism from spreading across the Sahel, the real problem was the widespread poverty in Mali and the surrounding region which needed to be better addressed in order to prevent such extremist groups from returning to the region. ${ }^{43}$ Even before France had launched Opération Serval, Chinese government officials had regarded the worsening situation in the Sahel region as a product of underdevelopment and diplomatic failures. In a December 2012 speech at the UNSC, Ambassador Li Baodong stressed that the solution for Mali and the surrounding region was not only improved international coordination of aid and assistance but also the requirement for regional governments and actors to take the lead in peace-building. ${ }^{44}$ Given its lack of experience in the region, Chinese forces needed to be reliant on the UN, other mission contributors, and local governments.

Finally, the Mali operations offered China an opportunity further establish itself as an alternative provider of security in the developing world, especially in the case of Africa. In Mali, a window was provided for China to contrast its peacekeeping and peacebuilding policies with that of France and the West as a whole. Beijing was at best ambivalent about the initial announcement of Opération Serval, and was concerned France was using the mission to cement a more permanent presence in the Sahel region, and that should France, alone, attempt to pacify Mali, it would eventually walk into a quagmire. ${ }^{45}$ The Chinese government's initial response to France's decision to send forces to Mali was reserved but not overtly critical. In the first official statement by the Chinese Foreign Ministry after operations began, the question of France's role was not addressed. ${ }^{46}$ Instead, the spokesperson condemned attacks by the rebel forces, affirmed Chinese support for the Malian government, and called for an 'Africa-led' intervention mission, consistent with Beijing's preferences for crises of this nature to be addressed by local actors when possible.

Moreover, as some China-based Africa analysts noted, France's intervention placed it in a much stronger diplomatic position vis-à-vis both China and the United States, especially since the Obama government did not send forces to Mali. It was also argued in one Chinese newspaper editorial that the decision by the Hollande government to intervene not only risked the same quagmire that the US encountered in Afghanistan, but also created the possibility for the 'legalization of a new interventionism in Africa', an unwelcome precedent in Beijing's view. As well, the article noted that 'France's involvement in Mali is still a risky business. One of the drawbacks of this action is that it brings back memories of the 'African gendarmerie' ${ }^{47}$ Another editorial in the same news agency noted that the West was seeking a stronger strategic presence in Africa, and suggested France might have had economic motives in intervening in Mali. The piece concluded by stating the Chinese government should not send either troops or financial support to Mali under the circumstances, a recommendation

\footnotetext{
${ }^{43}$ Yu, 2013; Gosset, 2013.

${ }^{44}$ China MFA, 10 December 2012.

${ }^{45}$ Yun, 2013.

${ }^{46}$ China MFA, 14 January 2013.

${ }^{47} \mathrm{He}, 2013$.
} 
which Beijing ultimately did not follow. ${ }^{48}$ By agreeing to participate in MINUSMA, China could shake off the label of 'free rider' in Africa while providing a balance to French and other Western personnel involved in Mali peacekeeping.

However, China's deeper engagement in UN peacekeeping operations, including in Mali, has also meant exposure by Chinese personnel to greater dangers which could challenge the country's commitment to peacekeeping in the future. ${ }^{49}$ The Mali mission has proven to be especially dangerous for foreign military and civilian personnel as the country continues to be vulnerable to terrorist and militant attacks. These vulnerabilities were tragically illustrated in June 2016 when Shen Liangliang, a Sergeant First Class with the PLA Ground Forces, was killed by an improvised explosive device near the Chinese barracks at Gao, with four other Chinese peacekeepers wounded. As with previous Chinese personnel who had been killed while serving on UN missions, Shen was honoured as a martyr (lieshi 烈士) for his sacrifice. ${ }^{50}$

The danger to Chinese civilians in the country, despite the UN presence, was also underscored by the November 2015 attack by Al-Mourabitoun, (or 'the Sentinels', an extremist group which operated in Sahel region in 2013-17), and AQIM militants on a hotel regularly used by foreign visitors in Bamako. The attack left three employees with the China Railway Construction Corp. dead along with eighteen other civilians and led to questions about whether Chinese peacekeepers should have played a greater role in protecting Chinese non-combatants. ${ }^{51}$ Chinese Foreign Minister Wang Yi referred to the deaths in Bamako as an 'inhuman atrocity'. Then in June 2017 an attack by militants from Jama'a Nusrat ul-Islam wa al-Muslimin, ('Group for the Support of Islam and Muslims'), or JNIM, a coalition of regional extremist groups loyal to Al-Qaeda, on a resort complex outside of Bamako left four dead, including a Chinese national. ${ }^{52}$

These events, as well as Chinese casualties in other UN peacekeeping missions in Africa including two Chinese fatalities in South Sudan in June 2016, prompted further debate within the Chinese government about the country's resolution to continue to maintain a strong commitment to these sorts of peacekeeping missions. ${ }^{53}$ Despite the still tenuous security situation in Mali, China has remained committed to seeing the successful conclusion of MINUSMA, underscored during a May 2017 meeting between Wang Yi and his opposite number in Bamako, Malian Foreign Minister Abdoulaye Diop, in Beijing, in which Wang confirmed that China was dedicated to bringing peace in the region as well as assisting Mali with economic development. ${ }^{54}$

\section{Relative Gains: The Benefits of Mali Intervention}

\footnotetext{
${ }^{48} \mathrm{Li}$ and Jin, 2013.

${ }^{49}$ Foot, 2014.

${ }^{50}$ Hua, 2016. Zheng, 2016. As of December 2017, eighteen Chinese personnel had been killed in the line of duty in UN peacekeeping missions.

${ }^{51}$ Zuo, 2015.

${ }^{52}$ Xinhua / BBC Monitoring, 21 November 2015; Bodeen, 2015; Sangare and Diarra, 2017.

${ }^{53}$ Page and Stevis, 2016.

54 MFA China, 8 November 2017.
} 
Until the recent diversification of China's African diplomacy under Xi Jinping, Beijing's primary diplomatic partners in Africa have traditionally been those states with much larger resource bases, including Angola, South Africa, Sudan/South Sudan and Zambia. What had made the Mali case a watershed for China's peacekeeping thinking was that the West African country was not a major source of Chinese trade. However, under Xi the Chinese government has taken on a more regional-level approach to African diplomacy in addition to bilateral ties, including via institutions such as the Belt and Road and FOCAC.

For example, during a March 2013 tour of African states shortly after taking office, President Xi stressed in Dar es Salaam, Tanzania, that China was poised to be an important economic power for the continent while avoiding the nationalism and hegemonism previously practiced by European great powers in Africa. ${ }^{55}$ The Forum on China-Africa Cooperation, founded in 2000, has recently become a platform for Chinese Belt and Road projects, including via the African Union (AU), and it was at FoCAC's Johannesburg Summit in December 2015 that President Xi outlined 'five pillars' of Sino-Africa cooperation, namely equality, economic cooperation, cultural exchanges, security cooperation and solidarity in international affairs. China's diplomacy in Africa has also been affected by the perceived American pullback from the continent under the US administration of Donald Trump. ${ }^{56}$

China's trade with the whole of Africa surpassed American and European levels in 2009 , and as of 2016 stood at US\$149.1 billion. Two new economic partners for China in Western Africa have also made the overall region more attractive to Beijing's regional trade policies, namely Gambia and São Tomé and Príncipe, which switched recognition from Taipei to Beijing in March and December 2016, respectively ${ }^{57}$ Specific Chinese trade with Mali stood at US\$465 million in 2016, compared with US\$189.2 million in 2006, and during that period China had become Mali's largest bilateral trading partner by the time the civil war broke out. ${ }^{58}$

The Malian government of President Ibrahim Boubacar Keïta officially pledged support for the Belt and Road process in 2017, and the country has benefitted from specific Chinese development projects spearheaded by Beijing, which has called for the building of Malian infrastructure and improving human resources, as well as agricultural cooperation. ${ }^{59}$ For example, in 2015 two Chinese firms agreed to complete the construction of a US\$750 million dam at Taoussa in northeastern Mali, and a hydroelectric plant built in Guinea in 2015 was providing electrical power two years later to Mali and neighbouring countries. Also, in December 2017 Beijing agreed to export five hundred tonnes of rice to Bamako to address the food insecurity situation in Mali. ${ }^{60}$ Thus, China's commitment to peace-building in Mali has also served to emphasise Beijing's overall commitment for regional partnership for the West African and Sahel regions, as that part of the continent develops as a sub-regional priority for Beijing.

\footnotetext{
${ }^{55}$ Buckley, 2013.

56 MFA China, 13 January 2018; Pilling, 2018; Xi, 2017, 496-501.

${ }^{57}$ Bush, 2016; New York Times / Associated Press, 26 December 2016.

${ }^{58}$ Qin, 2017; Xinhua, 11 May 2017; Xinhua's China Economic Information Service, 2017; MFA China, August 2017.

${ }^{59}$ Xinhua, 23 May 2017; French, 2014, 142-84.

${ }^{60}$ AllAfrica / Factiva, 24 May 2017; Global Energy Research / Factiva, 4 February 2018; Infos Plus Gabon, 17 December 2017; Shanghai Daily, 12 May 2017.
} 
In addition to the economic dimension of China's Mali engagement, there have also been opportunities for Beijing to continue to expand its regional security diplomacy. For example, in December 2017, a Chinese engineering detachment held a joint drill in Mali with Nigerien peacekeepers in Ménaka, a region in Mali which had experienced several terrorism attacks during that year. China has also begun to cooperate more closely with France in the region, in recognition of mutual concerns over instability and terrorism in the Sahel region. This has included Chinese support promised by President Xi to French President Emmanuel Macron for the 'G5-Sahel' anti-terrorism force which began operations in Mali in December 2017 and includes local Malian forces along with troops from the other four Sahel nations, Burkina Faso, Chad, Mauritania and Niger, and is supported by French forces as part of Opération Barkhane, in place since 2014. After years of rocky Sino-French relations under the administrations of Nikolas Sarkozy and François Hollande in Paris, closer security cooperation in Africa may ultimately be the catalyst for growing bilateral cooperation. ${ }^{61}$

\section{Conclusion: The Hard Lessons of Mali}

It is telling that a 2017 movie, 'Wolf Warrior II' (Zhan Lang 2 战狼 2), which became the highest grossing film in China to date, tells the story of a disgraced PLA operative battling rebels and mercenaries in an unnamed African country while rescuing stranded Chinese civilians, ${ }^{62}$ a nod to both China's unease about its newly developed security roles internationally, and also to the country's growing confidence in its ability to protect its people and assets abroad. China's peacekeeping, as well as other Africa MooTw operations in recent years, such as PLA Navy participation in counter-piracy operations off the Somalian coast and Chinese medical assistance provided to Western Africa during the Ebola virus outbreak in 2013-6, further raised China's public support for these sorts of missions, as well as improving China's image in Africa. ${ }^{63}$

There have been indications that China's presence in Mali has been viewed as largely positive from an economic viewpoint, one example being a 2016 survey by Afrobarometer published in which $90 \%$ of respondents in Mali suggested that there was 'some/a lot' of Chinese economic influence in Mali, and that 92\% believed China had a 'somewhat positive' or 'positive' influence on the African state's economy. However, there are also concerns that the closeness of the China-Mali economic relationship remains a source of unease among Malians. ${ }^{64}$ Although the hard economic benefits of Chinese peacekeeping in Mali are unlikely to grow significantly, as China continues to deepen its overall African engagement in the diplomatic, economic and strategic fields, Mali has become an important component in a larger strategy of Chinese comprehensive diplomacy in Africa.

As China continues to rethink its traditional policies towards humanitarian intervention in many parts of the world, Mali has demonstrated the addition of a new variable, namely that several trouble spots in the world are becoming either part of or close to Beijing's expanding network of trade and aid partners. In May 2013, as Beijing was preparing its response to the Malian conflict, a spokesperson for the Chinese Foreign Ministry noted that his country was ready to build a more visible presence in Africa 'as a responsible major

\footnotetext{
61 ‘France 24, 12 January 2018; Le Tribune, 5 January 2018; Xing, 2014.

${ }^{62}$ Callick, 2017.

${ }^{63}$ Blasko, 2012, 220-3; Cui, 2017.

64 ‘Afrobarometer Dispatch, 2016), Diakon and Röschenthaler, 2017.
} 
power with a more neutral stance in the field. ${ }^{65}$ Therefore, Beijing cannot as readily play the bystander, or the balancer, in future cases of civil conflict on the continent, especially given Africa's central placement the developing Belt and Road trade routes. However, success or failure of Chinese policies in Mali will not only affect participation in future UNPKO missions on the continent, but also the ability of Beijing to continue to act as a more effective security guarantor, as well as political and economic partner, for Africa.

China's decision to support the more robust peacekeeping role for Mali also suggests that Beijing was becoming more comfortable with UN combat missions under certain situations and in select regions including Africa. Moreover, China has now begun the process of further formalising its security interests in Africa with the July 2017 opening of a 'logistics support base' in Djibouti, the first official Chinese overseas military installation. ${ }^{66}$ This facility could augment Chinese monitoring capabilities of its interests in East Africa and the Middle East and act as a support mechanism for current and future peacekeeping and like missions. With China continuing to develop its African engagement, there will be greater pressure placed on Beijing not only to demonstrate its economic commitment to the continent but also to prove that China is more willing to provide security as well as economic cooperation for its African partners. The Mali UN operation will continue to be a critical test of that resolve.

Marc Lanteigne is a Senior Lecturer (China, East Asia, Polar Regions) at the Centre for Defence and Security Studies (CDSS), at Massey University in Auckland, New Zealand. His research interests include Chinese and East Asian foreign policy, China's engagement and cooperation with regional and international organisations, cross-regional diplomacy, Arctic and Antarctic politics and security, Sino-European relations, and non-traditional security in Asia. He is the author of China and International Institutions: Alternate Paths to Global Power (2005) and Chinese Foreign Policy: An Introduction (2015), as well as numerous articles on China and East Asia politics.

\section{摘要}

2013 年是中国加大在联合国维和行动里程碑式的一年。在马里陷入内战后, 北京同意 向其派遣大批人员以支持联合国维和行动, 包括第一次派出安全部队。中国在其他一 些非洲国家也有维和人员，但因马里并非中国在非洲大陆主要的贸易伙伴，因此在此 的维和投入显得非常引人注目。这次行动巩固了北京加深建立与非洲伙伴关系的目标 ，也展示了中国政府不仅限于追求 “资源外交” 的决心还有更全面参与非洲事务的方 法。尽管中国向来对参与在内部冲突情况下的人道主义干预怀有兴趣，马里依然是检 验其是否有能力在一个正面临着持续暴力冲突的国家参与联合国维和行动的重要试金 石。马里行动既是北京维和政策向 “现实政治” 转变过程中的重要一步, 也和中国目 前的大国地位相关联。同时，参与此次行动对中国有所裨益，不但利于建立中国在非 洲的维和信誉, 也有助于凸显中国在其他国家内战情况下如何进行干预的日渐鲜明的 观点。

关键词: 中国; 马里; 维和; 非洲; 联合国; 联合国马里多层面综合稳定团

\footnotetext{
${ }^{65}$ Zhao, 2013.

${ }^{66}$ Gao, 2017.
} 


\section{Bibliography}

Afrobarometer Dispatch. 2016. "China's growing presence in Africa wins largely positive popular reviews," 122. 24 October.

http://afrobarometer.org/sites/default/files/publications/Dispatches/ab_r6_dispatchno122_perceptions_of_china_ in_africa1.pdf.

AllAfrica / Factiva. 2017. "China pledges further cooperation with Mali in agricultural, industrial development,", 24 May.

Avezov, Xenia and Timo Smit. 2014. "The consensus on Mali and international conflict management in a multipolar world," SIPRI Policy Brief, September, https:/www.sipri.org/sites/default/files/files/misc/SIPRIPB1403.pdf

Bo Zhou. 2017 "How China can improve UN peacekeeping: the right way for Beijing to step up," Foreign Affairs, 15 November. https:/www.foreignaffairs.com/articles/china/2017-11-15/how-china-can-improve-unpeacekeeping.

Black, Ian. 2013. "Mali militants: who's who Among Islamist rebels," The Guardian, 16 January.

Blasko, Dennis J. 2012. The Chinese Army Today. $2^{\text {nd }}$ ed. London and New York: Routledge.

Bodeen, Christopher. 2015. "Militant attacks abroad a diplomatic quandary for China's Xi," Associated Press, 25 November.

Boeke, Sergei and Bart Schuurman 2015. "Operation 'Serval': A strategic analysis of the French intervention in Mali, 2013-2014,” Journal of Strategic Studies 38(6), 801-25.

Brautigam, Deborah. 2009. The Dragon's Gift: The Real Story of China in Africa. Oxford: Oxford University Press.

Buckley, Chris. 2013. “China's leader tries to calm African fears of his country's economic power," The New York Times, 25 March.

Bush, Richard C. 2016. "China's Gambia gambit and what it means for Taiwan," Brookings, 22 March. https:/www.brookings.edu/blog/order-from-chaos/2016/03/22/chinas-gambia-gambit-and-what-it-means-fortaiwan/.

Bøås, Morten and Liv Elin Torheim. 2013. “The trouble in Mali- corruption, collusion, resistance,' Third World Quarterly 34(7), 1279-92.

Callick, Rowan. 2017. "Wolf Warrior II: patriotic Chinese Rambo blows up box office,” The Australian, 12 August.

Chandler, Allison and Benno Zogg. 2017. "Mali: une paix fragile," ("Mali: A Fragile Peace”) ETH - Centre for Security Studies CSS Analysis 215, https://doi.org/10.3929/ethz-b-000200576.

Chen, Jing. 2009. "Explaining the change in china's attitudes towards UN peacekeeping: A norm change perspective,' Journal of Contemporary China 18(58), 157-73.

China Daily. 2016. "China to become $2^{\text {nd }}$ largest contributor to UN peacekeeping budget”, 30 May 2016, $<$ http://europe.chinadaily.com.cn/world/2016-05/30/content_25536341.htm>.

Clemens, Morgan. 2016. "PLA thinking on military operations other then war," China's Evolving Military Strategy, ed. James McReynolds. Washington DC: Jamestown.

Cristiani, Dario and Riccardo Fabiani. 2013. "From disfunctionality to disaggregation and back? The Malian crisis, local Players and European interests," Istituto Affari Internzionali, IAI Working Papers 13-08. 
Cui Xiaotao. 2017. "China-Africa relations in 2015: more practical cooperation for strategic goals," CIIS Blue Book on International Situation and China's Foreign Affairs (2016). Beijing: World Affairs Press, 497-511.

Diakon, Birama and Ute Röschenthaler. 2017. "The Chinese presence in the Malian mediascape,” Journal of African Cultural Studies 29(1), 96-113.

Ehizuelen, Michael Mitchell Omoruyi and Hodan Osman Abdi. 2017. "Sustaining China-Africa relations: slotting Africa into China's One Belt, One Road Initiative makes economic sense," Asian Journal of Comparative Politics 20(10), 1-26.

Elischer, Sebastian. 2013. “After Mali comes Niger: West Africa’s problems migrate east,” Foreign Affairs, 12 February, https://www.foreignaffairs.com/articles/mali/2013-02-12/after-mali-comes-niger.

English, Charlie. 2017. The Book Smugglers of Timbuktu: The Quest for this Storied City and the Race to Save its Treasures, London: William Collins.

Evans, Paul M. 2004. "Human security in East Asia: in the beginning," Journal of East Asian Studies 4(2), 26384.

Fassy, Thomas. 2012. "Gaddafi's influence in Mali’s coup,” BBC News, 22 March, http://www.bbc.com/news/world-africa-17481114.

Feng, Bree. 2014. “Obama’s 'Free Rider' comment draws Chinese criticism,” The New York Times, 13 August.

Foot, Rosemary. 2014. “ 'Doing some things' in the Xi Jinping era: The United Nations as China's venue of choice," International Affairs 90(5), 1085-1100.

France 24 / Associated Press . 2013. “Timbuktu falls to Tuareg rebels amid post-coup chaos,”, 1 April.

France Diplomatie. 2012. "Speech by M. François Hollande, President of the Republic, to the National Assembly of Senegal - Dakar, 12 October 2012,", 12 October, http://basedoc.diplomatie.gouv.fr/vues/Kiosque/FranceDiplomatie/kiosque.php?fichier=baen2012-10-19.html.

French, Howard W. 2014. China's Second Continent: How A Million Migrants Are Building a New Empire in Africa. New York: Knopf.

Fravel, M. Taylor. 2001. "Economic growth, regime insecurity, and military strategy: explaining the rise of noncombat operations in China," Asian Security 7(3), 177-200.

Fung, Courtney J. 2016. “China's troop contributions to UN peacekeeping," United States Institute of Peace Peace Brief, 26 July. https://www.usip.org/publications/2016/07/chinas-troop-contributions-un-peacekeeping.

Gadzala, Aleksandra W. 2015. Africa and China: How Africans and Their Governments are Shaping Relations with China, Lanham, MA: Rowman and Littlefield.

Gao, Charlotte. 2017. "China officially sets up its first overseas base in Djibouti," The Diplomat, 12 July, https://thediplomat.com/2017/07/china-officially-sets-up-its-first-overseas-base-in-djibouti/.

Garwood-Gowers, Andrew. 2012. "China and the 'responsibility to protect': the implications of the Libyan intervention,” Asian Journal of International Law 2, 375-93.

Gill, Bates and Chin-Hao Huang. 2009. "China's expanding peacekeeping role: its significance and policy implications," SIPRI Policy Brief. February.

Global Energy Research / Factiva. 2018. 'Mali - projects - electricity - hydro,', 4 February.

Gosset, David. 2013. "Time to defeat poverty in Mali,” China Daily, 25 January.

Hammer, Joshua. 2014. "The race to save Mali’s priceless artefacts,” The Smithsonian, http://www.smithsonianmag.com/history/Race-Save-Mali-Artifacts-180947965/. 
Hanauer Larry and Lyle J. Morris. 2014. Chinese Engagement in Africa: Drivers, Reactions, and Implications for US Policy, Washington, DC: Rand.

http://www.rand.org/content/dam/rand/pubs/research_reports/RR500/RR521/RAND_RR521.pdf.

He Wenping. 2013. "Hollande has set alarming precedent for intervention," Global Times, 23 January.

Heisbourg, François. 2013. “A surprising little war: first lessons of Mali,” Survival 55(2): 7-18.

Hille, Kathrin. 2013. "China commits combat troops for Mali," Financial Times, 28 June.

Hirono, Miwa. 2011. "China's charm offensive and peacekeeping: The lessons of Cambodia - what now for Sudan?” International Peacekeeping 18(3), 328-43.

Hirono, Miwa and Marc Lanteigne. 2012. "Introduction: China and UN peacekeeping,' China's Evolving Approach to Peacekeeping, ed. Marc Lanteigne and Miwa Hirono. London and New York: Routledge, 1-14.

Holsag, Jonathan. 2009. “Embracing Chinese global security ambitions," Washington Quarterly 32(3), 105-18.

Human Rights Watch. 2017. "Mali: events of 2017," 21 December. https://www.hrw.org/worldreport/2018/country-chapters/mali.

Hua Xia. 2016. "Chinese peacekeeper’s body brought home from Mali,” Xinhua, 9 June.

Huang, Kristin. "Chinese peacekeepers in tense stand-off with armed militants in South Sudan," South China Morning Post, 6 January 2018.

Infos Plus Gabon. 2017. "Plus de 5400 tonnes de riz de la Chine pour lutter contre l'insécurité alimentaire au Mali," ("More than 5400 tonnes of rice from China to fight against food insecurity in Mali"), 17 December, https://infosplusgabon.com/index.php/actualites/submenu-1/7950-plus-de-5400-tonnes-de-riz-de-la-chine-pourlutter-contre-linsecurite-alimentaire-au-mali.

Lacocq, Baz, Gregory Mann, Bruce Whitehouse, Dida Badi, Lotte Pelckmans, Nadia Belalimat, Bruce Hall and Wolfham Lacher. 2013. "One hippopotamus and eight blind analysts: A multi-vocal analysis of the 2012 political crisis in the divided republic of Mali," Review of African Political Economy 40(137), 346-7.

Lanteigne, Marc. 2011. "A change in perspective: China's engagement in the East Timor UN peacekeeping operations," International Peacekeeping 18(3), 313-27.

Li Jian and Jin Jing, "Zhongguo zai Mali bu chubing ye bu chu qian jun fang cheng zhan hou keyi weihe," ("China will neither send troops to Mali, nor will it give money"), Global Times / Sohu.com, 22 January 2013, $<\mathrm{http}: / /$ mil.sohu.com/20130122/n364250702.shtml>.

"Macron revives France's partnership with China in Africa," France 24, 12 January 2018,

http://www.france24.com/en/20180111-france-china-africa-macron-resuscitates-partnership-security-g5-sahelclimate-investment.

Ministry of Foreign Affairs for the People's Republic of China, 2000. "Some thoughts on establishing a new regional security order, (Statement by Ambassador Sha Zukang)" 7 August, http://www.fmprc.gov.cn/eng/wjdt/zyjh/t24961.htm.

Ministry of Foreign Affairs of the People's Republic of China. 2012. "Statement by Ambassador Li Baodong at the Security Council Ministerial Meeting on the Sahel Region situation - From Chinese Mission to the United Nations", 10 December, http://www.china-un.org/eng/hyyfy/t1109431.htm.

Ministry of Foreign Affairs of the People's Republic of China. 2013. "2013 Nian 1 yue 14 ri waijiao bu fayan ren hong lei zhuchi li xíng jìzhe hui," ("Foreign Ministry spokesperson Hong Lei’s regular press conference on 14 January"), http://www.fmprc.gov.cn/web/fyrbt_673021/jzhsl_673025/t1004906.shtml. 
Ministry of Foreign Affairs of the People's Republic of China. 2017. "Zhongguo tong Mali de guanxi," (“The relationship between China and Mali”). August, http://www.fmprc.gov.cn/chn//gxh/cgb/zcgmzysx/fz/1206_33/1206x1/t6607.htm.

Ministry of Foreign Affairs of the People's Republic of China. 2017. "Wang Yi meets with Minister of Foreign Affairs Abdoulaye Diop of Mali,", 8 November, http://www.fmprc.gov.cn/mfa_eng/zxxx_662805/t1509004.shtml.

Ministry of Foreign Affairs of the People's Republic of China. 2018. "Wang Yi talks about the FOCAC Beijing summit: jointly build the 'Belt and Road' and elevate China-Africa mutually beneficial cooperation to new highs,”, 13 January. http://www.fmprc.gov.cn/mfa_eng/Zxxx_662805/t1525999.shtml.

Ministry of National Defence of the People's Republic of China. 2018. "Chinese peacekeepers to Mali awarded UN Peace Medals of Honor,” 24 February. http://eng.mod.gov.cn/news/2018-02/24/content_4805315.htm.

Murray, Craig. 2013. "China to deploy 'security force' to UN peacekeeping operation in Mali," US-China Economic and Security Review Commission Staff Research Backgrounder, 9 July.

New York Times / Associated Press. 2016. "China resumes ties With São Tomé, which turned away From Taiwan,", 26 December.

Page, Jeremy and Matina Stevis. 2016. 'China discovers the price of global power: soldiers returning in caskets,' Wall Street Journal, 15 November.

Pang, Zhongying. 2009. “China's non-intervention question,” Global Responsibility to Protect 1: 237-52.

2012. "Issues in the transformation of China's engagement with international peacekeeping," Not Congruent but Quite Complementary: U.S. and Chinese Approaches to Non-traditional Security ed. Lyle J. Goldstein. Newport, RI: China Maritime Studies Institute, Naval War College, 54-5.

People’s Daily. 2009. “Chinese president meets Malian parliament leader on ties,” People's Daily, 14 February. 2013. "First Chinese peacekeeping force to Mali completes concentrated training,", 20 November.

Pilling, David. 2018. "US abdication in Africa hands political opportunities to China," Financial Times, 7 February.

Poh, Angela and Mingjiang Li. 2017. "A China in transition: the rhetoric and substance of Chinese Foreign Policy under Xi Jinping," Journal of Contemporary China 13(2): 84-97.

Polgreen, Lynda and Scott Sayare, 2013. "With Timbuktu retaken, France signals Its plans to pull back in Mali," The New York Times, 28 January.

Qin Zhongwei. 2017. “Africa seeks to learn a lesson from China,” China Daily, 16 February 2013.

Rettman, Andrew. 2012. "Mali coup is ‘spill-over' from EU-led war in Libya,” EU Observer, 28 March 2012, https://euobserver.com/foreign/115733.

Sangare, Idrissa and Adama Diarra. 2017. "Al-Qaeda-linked group claims deadly attack at Mali resort," Reuters, 19 June.

Shanghai Daily, 2017. "Chinese workers help bring prosperity to countries along Belt and Road," Shanghai Daily, 12 May.

Shaw, Scott. 2013. "Fallout in the Sahel: The geographic spread of conflict from Libya to Mali," Canadian Foreign Policy Journal 19(2), 199-210.

Snetkov, Aglaya and Marc Lanteigne. 2015. " 'The loud dissenter' and its 'cautious partner' - Russia, China, global governance and humanitarian intervention," International Relations of the Asia-Pacific International Relations of the Asia-Pacific 15, 113-46. 
Teitt, Sarah. 2011. “The responsibility to protect and China's peacekeeping policy,' China's Evolving Approach to Peacekeeping, ed. Marc Lanteigne and Miwa Hirono. New York and London: Routledge, 56-70.

Le Tribune. 2018. "En voyage officiel en Chine, Macron compte bien signer de nombreux contrats," ("On an official trip to China, Macron expects to sign many agreements"), 5 January.

United States General Accounting Office. 2018. "UN peacekeeping: cost estimate for hypothetical U.S. operation exceeds actual costs for comparable UN operation,", February.

https://www.gao.gov/assets/690/689900.pdf.

Verhoeven, Harry. 2014. "Is Beijing's non-interference policy history? How Africa is changing China," Washington Quarterly 37(2), 55-70.

Wang Xin, 2012. "Weihe xue chuanglì de pingpan- weihe xue chuyi zhi”, ("On the founding of peacekeeping discipline”) Hunan jingcha xueyuan xuebao (Journal of Hunan Police Academy) 1, 138-43.

Wing, Susanna D. 2013. "Briefing - Mali: politics of a crisis,” African Affairs 112(248), 476-85.

Wing, Susanna D. 2015. “'Hands off my constitution': constitutional reform and the workings of democracy in Mali,” Journal of Modern African Studies, 53(3), 451-75.

Xi Jinping. 2017. "A new partnership of mutual benefit and a community of shared future, (speech at the General Debate of the $70^{\text {th }}$ Session of the UN General Assembly at the UN Headquarters in New York, 28 September 2015," The Governance of China II Beijing: Foreign Languages Press, 569-75.

2017. “A New Era of China-Africa cooperation and common development, December 4, 2015,' $X i$ Jinping: The Governance of China II. Beijing: Foreign Languages Press, 496-501.

Xinhua. 2013. "China sends security force for peacekeeping mission in Mali”. 5 December.

2015. "Chinese foreign minister terms Mali hotel attack 'inhuman atrocity", 21 November.

2017. “China-Africa trade surges in Q1,”, 11 May.

2017. “China to Dispatch $5^{\text {th }}$ peacekeeping Force to Mali,' Xinhua, 11 May.

2017. 'Chinese FM pledges further cooperation with African countries on Belt and Road,' 23 May.

2018. 'China to send 395 peacekeepers to Mali,' 19 April.

Xinhua's China Economic Information Service / Factiva. 2017. “China's trade with Mali in February 2007', 25 April.

Xing Hua. 2014. "The past, present and future of Sino-French relations," China's New Diplomacy and Changing World, ed. Qu Xing, Beijing: World Affairs Press, 348-64.

Yong Deng. 2016. "Reputation and the security dilemma: China reacts to the China threat theory," New Directions in the Study of Chinese Foreign Policy, ed. Alastair Iain Johnston and Robert S. Ross, (Stanford: Stanford University Press, 2006), 186-214.

Yu Jincui. 2013. "Mali conflict shows dangers of leaving Africa in poverty,” Global Times, 18 January.

Yun Sun. 2013. “How China views France’s intervention in Mali: An analysis,' Brookings, 23 January, https://www.brookings.edu/opinions/how-china-views-frances-intervention-in-mali-an-analysis/.

Zajec, Oliver. 2013. “The Mali intervention,” Le Monde Diplomatique (English) 1302, 1-3.

Zhao Shengnan. 2013. "China offers to provide peacekeepers to Mali," China Daily, 24 May. 
Zheng Chen. 2016. “China and the responsibility to protect,' Journal of Contemporary China 25(101), 686-700.

Zheng Jinran, 2016. "Return of a hero,” China Daily, 10 June.

Zheng, Sarah. 2017. "China completes registration of 8000-strong UN Peacekeeping force, Defence Ministry Says,' South China Morning Post, 29 September.

Zuo, Mandy. 2015. "Chinese troops did not 'fail' hostages in Mali hotel siege, military experts say," South China Morning Post, 22 November. 